\title{
28. MINERAL COMPOSITIONS AND CRYSTALLIZATION TRENDS IN DEEP SEA DRILLING PROJECT HOLES 417D AND $418 A^{1}$
}

\author{
John M. Sinton, Hawaii Institute of Geophysics, University of Hawaii, Honolulu, Hawaii \\ and \\ Gary R. Byerly, Department of Geology, Louisiana State University, Baton Rouge, Louisiana
}

\begin{abstract}
Crystallization sequences in all units of both Holes 417D and 418A follow the order: (spinel), plagioclase \pm spinel, plagioclase + olivine \pm spinel, plagioclase + olivine + clinopyroxene, plagioclase + clinopyroxene + magnetite, and plagioclase + magnetite + quartz \pm clinopyroxene \pm apatite. Spinel is a common groundmass phase in the least-fractionated unit (418A lithologic Unit 6), but also occurs as rounded grains in some more-fractionated units. Analyzed olivine compositions range from Foss to Foz9.5, and show a moderate correlation with the $\mathrm{Mg} / \mathrm{Fe}$ ratio of the host glass. The presence of clinopyroxene is largely controlled by the degree of crystallinity of the sample, but is more abundant as a phenocryst phase in the more fractionated units. Cpx first appears as homogeneous rounded, and possibly resorbed, grains with high $m g[=\mathrm{Mg} /(\mathrm{Mg}+\mathrm{Fe})]$. Later development of $\mathrm{cpx}$ is as sector-zoned intergrowths with plagioclase, and still later interstitial grains. There is a continuous decrease in $m g(0.88$ to 0.46$)$ and an increase in $\mathrm{Ti} / \mathrm{Al}$ in cpx through this crystallization sequence. Glomeroporphyritic clots of $\mathrm{cpx} \pm$ plag are cognate and include both early- and middle-stage cpx compositions. Late-stage subcalcic augite $(\mathrm{CaO}<14$ wt. \%) co-exists with pigeonite ( $m g=0.64$ to 0.68 ) in some massive units. Plagioclase phenocryst compositions range from An91 to $\mathrm{An}_{59}$ and analyzed groundmass grains range from $A_{76}$ to $A_{26}$. Initiation of pyroxene crystallization is marked in feldspar composition by a change from nearly constant $\mathrm{Fe}$ contents to gradually increasing $\mathrm{Fe}$ with $\mathrm{Ab}$ content. The beginning of crystallization of $\mathrm{Fe}$-Ti oxides is marked by inflections in the feldspar and pyroxene compositional trends. Textural evidence supports the conclusion based on plagioclase and clinopyroxene inflections, that magnetite starts to form only after crystallization has proceeded to where plagioclase has the composition An 60 to 65 , and the $\mathrm{Mg} /(\mathrm{Mg}+\mathrm{Fe})$ ratio of clinopyroxene $=0.72$ to 0.75 . Local disequilibrium textures and compositions may indicate some mixing of magmas, but the pyroxene compositions generally indicate crystallization from rising and fractionating magmas, possibly with increasing silica activities. Late-stage segregation patches from greater than 95 per cent crystallization contain $\mathrm{Na}$ plagioclase $\left(\mathrm{An}_{16}\right.$ to $\left.\mathrm{An}_{38}\right)$, quartz, oxides, and possibly apatite. These "trondhjemitic" patches represent the first direct evidence that ocean floor basaltic liquids may evolve to high $\mathrm{Si}$, high $\mathrm{Na} / \mathrm{K}$ differentiates.
\end{abstract}

\section{INTRODUCTION}

DSDP Sites 417 and 418 are located in Cretaceous crust (anomaly $M 0$ ) in the western Atlantic Ocean near $25^{\circ} \mathrm{N}$, $68^{\circ} \mathrm{W}$. Abundant relatively fresh basement material was drilled at Holes 417D and 418A; the average recovery rate for each hole was 72 per cent. Such high recovery rates, combined with relatively deep basement penetration ( $366 \mathrm{~m}$ at $417 \mathrm{D}, 544 \mathrm{~m}$ at $418 \mathrm{~A}$ ) provide a unique opportunity for detailed studies of oceanic crust.

Fourteen lithologic units were identified in the Hole 417D basement cores and 16 were identified in the Hole 418A

\footnotetext{
'HIG Contribution No. 997.
}

basement cores. Individual lithologic units are defined partly on structure (i.e., massive, pillowed, or breccia), and partly on mineralogical constitution (e.g., presence or absence of pyroxene phenocrysts, or spinel). On the basis of glass compositions, the recovered samples from both holes can be assigned to 22 chemical types (Byerly and Sinton, this volume). These chemical types generally reflect relative degrees of differentiation from primary liquids.

\section{PETROGRAPHY}

\section{Pillow Lavas}

Aphyric pillow lavas are notably rare in both Holes 417D and $418 \mathrm{~A}$, although some horizons generally less than 1 
meter in thickness are present locally (e.g., in Sections 417D-43-3, 417D-64-4, and 418A-18-5; and Cores 418A25 and 418A-26). These probably represent flow segregation of phenocrysts from liquids, and not lavas which have undergone little or no crystallization. Other samples are dominated by plagioclase phenocrysts up to $1 \mathrm{~cm}$ in size, comprising up to 35 per cent of some samples. Plagioclase phenocryst morphology varies from nearly anhedral in some large grains to euhedral microphenocryst laths (Plate $\mathrm{x}$ ). Large, relatively unzoned, plagioclase grains locally contain inclusions of Cr-spinel (417D lithologic Sub-unit 1C, 418A lithologic Units 6 and 16). Other plagioclase phenocrysts commonly display oscillatory zoning. Euhedral olivine phenocrysts, up to $1 \mathrm{~cm}$ in size, are common in almost all pillow basalts, but are typically smaller and less abundant than plagioclase phenocrysts.

Although some clinopyroxene phenocrysts ${ }^{2}$ can be found in all lithologic units, they are exceedingly rare in Hole 417D (Sub-unit 1A and Unit 11) and Hole 418A (Units 1, 6, and 15). Where present in these units, they are rounded and possibly resorbed (Plate 2). In other units, clinopyroxene morphology varies from rounded, discrete grains, to subhedral intergrowths with other pyroxene grains or plagioclase, or to local, nearly euhedral prismatic grains. Sector zoning is apparent in some pyroxene phenocrysts. Glass inclusions are locally preserved in plagioclase, olivine, and clinopyroxene phenocrysts (see Byerly and Sinton, this volume).

A variety of rapid cooling or quench textures similar to those described by Bryan (1972b) and Lofgren (1974) characterize pillow basalt groundmasses. Spherulitic textures mark the boundaries between outer glassy selvages and pillow interiors. Skeletal and other rapid growth morphologies are well developed in groundmass plagioclase, pyroxene, and magnetite (Plate 1).

\section{Massive Units}

Massive units are locally holocrystalline although up to 5 per cent devitrified glass is common in many samples. Textures tend toward ophitic or subophitic with minor plagioclase, olivine, and/or clinopyroxene phenocrysts. Latestage granophyric textures (Plate 3) occur in some of the thicker massive units.

\section{Crystallization Sequences}

Spinel is the liquidus phase in the least-fractionated units, followed in order by olivine, clinopyroxene, and magnetite. Although different units show different ranges in the degree of crystallinity, the order of appearance of the mineral phases is constant throughout both holes. This order follows the following sequence: (spinel), plagioclase \pm spinel, plagioclase + olivine \pm spinel, plagioclase + olivine + clinopyroxene, plagioclase + clinopyroxene \pm olivine, plagioclase + clinopyroxene + magnetite, and plagioclase + magnetite + quartz \pm clinopyroxene \pm apatite. Pigeonite is a local late-stage pyroxene in some massive units.

\footnotetext{
2 "Phenocryst" is here used to denote large, conspicuous crystals which are probably cognate but are not necessarily in equilibrium with the host glass or groundmass minerals.
}

\section{Alteration}

Although the scope of this paper does not include detailed alteration studies, certain low-temperature effects limit the amount of information that is available for interpreting the igneous petrogenesis of the samples. Basement sections in both Holes 417D and 418A are for the most part unaltered; fresh glass has survived throughout much of the sections. However, olivine is mainly preserved in unaltered glassy horizons, being replaced by calcite or phyllosilicates + oxides in pillow interiors and in massive units. Consequent$1 y$, the composition of olivine representing advanced stages of crystallization has not been determined.

\section{MINERAL CHEMISTRY}

All mineral analyses reported here were obtained with the 9-channel ARL-SEMQ microprobe at the Smithsonian Institution National Museum of Natural History in Washington, D.C. Operating conditions, standards, and data reduction procedures are given in Sinton, 1979.

\section{Spinel}

Bryan (1972a) noted that spinel is absent or rare in abyssal plagioclase tholeiites. This conclusion generally holds for the Hole 417D and 418A samples, although spinel is present in Hole 417D lithologic Sub-unit 1C and Unit 4, and is abundant in the least-fractionated units (Hole 418A Units 6 and 16). In Hole 417D samples, spinel mainly occurs as 20 to $100 \mu \mathrm{m}$ inclusions in large plagioclase phenocrysts, although a single rounded spinel, $0.6 \mathrm{~mm}$ in diameter, is present in Sample 417D-30-5, 106-110 cm, and a similar $100 \mu \mathrm{m}$ grain occurs in the groundmass of Sample 417D$39-4,75-82 \mathrm{~cm}$. Spinels are especially abundant in Hole 418A lithologic Unit 6 where they occur as inclusions in plagioclase and as skeletal microphenocrysts, commonly associated with olivine (Plate 2). Spinel analyses (Table 1) indicate that the skeletal spinels tend toward lower $\mathrm{Mg} /(\mathrm{Mg}$ $+\mathrm{Fe}^{2+}$ ) and higher $\mathrm{Ti}$ contents than included or rounded spinels; this probably reflects later stage crystallization of the skeletal grains.f

\section{Olivine}

Analyzed olivine phenocrysts (Table 2) range in composition from Fo87.9 to Fo79.5. CaO contents are remarkably constant in the range $0.34 \pm 0.05 \mathrm{wt}$. per cent, although some phenocryst rims range up to $>0.40$ wt. per cent $\mathrm{CaO}$. Although there is considerable range of olivine $\mathrm{Mg} / \mathrm{Fe}$ in many samples, there is a general correlation of the most Fe-rich olivine composition in each sample with $\mathrm{Mg} /(\mathrm{Mg}+$ $\mathrm{Fe}^{2+}$ ) of the host glass (Figure 1). For the more mafic glasses, the observed relationship is consistent with equilibrium crystallization (Figure 1). Olivine in the less mafic glasses is slightly more magnesian than that predicted by the data of Roedder and Emslie (1970). This discrepancy may reflect several possible considerations including (1) unrepresentative analyses of olivine in the Fe-rich glasses, (2) possible microprobe analytical bias, (3) compositional effects in the Hole 417D, 418A glasses which affect equilibrium partitioning in a manner not represented by the experimental runs of Roedder and Emslie (1970), (4) kinetic effects limiting attainment of equilibrium in the less mafic, lower temperature crystallizing liquids, and (5) complica- 
TABLE 1

Representative Analyses of Spinel

\begin{tabular}{|c|c|c|c|c|c|c|}
\hline \multirow{5}{*}{$\begin{array}{c}\text { Hole } \\
\text { Lithologic Unit } \\
\text { Sample } \\
\text { (Interval in cm) } \\
\text { Occurrence } \\
\text { Anal. }\end{array}$} & \multicolumn{3}{|c|}{$417 \mathrm{D}$} & \multirow{2}{*}{\multicolumn{3}{|c|}{$\begin{array}{c}418 \mathrm{~A} \\
6 \mathrm{~B}\end{array}$}} \\
\hline & \multicolumn{2}{|c|}{ IC } & \multirow{2}{*}{$\begin{array}{c}4 \\
39-4, \\
75-82\end{array}$} & \multicolumn{2}{|r|}{$6 \mathrm{~B}$} & \\
\hline & \multicolumn{2}{|c|}{$\begin{array}{c}30-5 \\
106-110\end{array}$} & & $\begin{array}{l}42-3, \\
17-23\end{array}$ & \multicolumn{2}{|c|}{$\begin{array}{r}\text { 48-3, } \\
46-49\end{array}$} \\
\hline & I & $\mathbf{R}$ & I & $\mathrm{s}$ & I & $\mathrm{s}$ \\
\hline & 1 & 2 & 3 & 4 & $s$ & 6 \\
\hline $\mathrm{SiO}_{2}$ & 0.12 & 0.10 & 0.09 & 0.13 & 0.11 & 0.13 \\
\hline $\mathrm{TiO}_{2}$ & 0.40 & 0.38 & 0.32 & 0.73 & 0.39 & 0.66 \\
\hline $\mathrm{Cr}_{2} \mathrm{O}_{3}$ & 37.0 & 38.6 & 27.9 & 37.6 & 32.9 & 35.8 \\
\hline $\mathrm{Al}_{2} \mathrm{O}_{3}$ & 21.8 & 27.3 & 34.9 & 24.0 & 32.5 & 25.9 \\
\hline $\mathrm{Fe}_{2} \mathrm{O}_{3}^{*}$ & 11.9 & 5.01 & 8.40 & 7.86 & 4.41 & 8.15 \\
\hline $\mathrm{FeO}^{*}$ & 12.1 & 13.4 & 8.84 & 15.6 & 12.1 & 15.4 \\
\hline $\mathrm{MnO}$ & N.A. & 0.18 & N.A. & 0.30 & 0.22 & 0.35 \\
\hline $\mathrm{MgO}$ & 15.1 & 15.2 & 18.8 & 13.3 & 16.3 & 13.7 \\
\hline $\mathrm{CaO}$ & 0.20 & 0.00 & 0.00 & 0.16 & 0.00 & 0.16 \\
\hline \multirow[t]{2}{*}{ Total } & 98.6 & 100.2 & 99.2 & 99.7 & 98.9 & 100.2 \\
\hline & \multicolumn{4}{|c|}{ Cations on the Basis of 4 Oxygens } & & \\
\hline $\mathrm{Si}$ & 0.003 & 0.003 & 0.003 & 0.004 & 0.003 & 0.004 \\
\hline $\mathrm{Ti}$ & 0.009 & 0.009 & 0.007 & 0.017 & 0.009 & 0.015 \\
\hline $\mathrm{Cr}_{\mathrm{r}}$ & 0.903 & 0.908 & 0.629 & 0.911 & 0.760 & 0.855 \\
\hline $\mathrm{Al}_{3+}$ & 0.793 & 0.957 & 1.172 & 0.867 & 1.119 & 0.922 \\
\hline $\mathrm{Fe}_{2+}^{3+}$ & 0.277 & 0.112 & 0.180 & 0.181 & 0.097 & 0.185 \\
\hline $\mathrm{Fe}^{2+}$ & 0.311 & 0.333 & 0.211 & 0.400 & 0.296 & 0.388 \\
\hline $\mathrm{Mn}$ & - & 0.005 & - & 0.008 & 0.005 & 0.009 \\
\hline $\mathrm{Mg}$ & 0.695 & 0.674 & 0.799 & 0.607 & 0.710 & 0.617 \\
\hline $\mathrm{Ca}$ & 0.006 & 0.000 & 0.000 & 0.005 & 0.000 & 0.005 \\
\hline$\Sigma \mathrm{R}^{3+}$ & 1.973 & 1.977 & 1.981 & 1.959 & 1.976 & 1.962 \\
\hline$\Sigma \mathrm{R}^{2+}-2 \mathrm{Ti}$ & 0.988 & 0.994 & 0.996 & 0.981 & 0.993 & 0.984 \\
\hline$\frac{\mathrm{Mg}}{2+}$ & & & & & & \\
\hline $\mathrm{Mg}+\mathrm{Fe}^{2+}$ & 0.691 & 0.669 & 0.791 & 0.603 & 0.705 & 0.614 \\
\hline
\end{tabular}

Note: ${ }^{*} \mathrm{FeO} / \mathrm{Fe}_{2} \mathrm{O}_{3}$ calculated assuming stoichiometric 3 cations per 4 oxygens. N.A.: Element not analyzed. I: Included in plagioclase phenocryst. R: Rounded grain in groundmass. S: Skeletal microphenocrysts (c.f. Plate 1). tions in partitioning induced by the presence of clinopyroxene as a crystallizing phase in the less mafic glasses.

\section{Plagioclase}

Plagioclase phenocryst core compositions range from $\mathrm{An}_{91}$ to $\mathrm{An}_{65}$ with low $\mathrm{K}$ and $\mathrm{Fe}$ contents (Table 3, Figure 2). Phenocryst rims range from An84 to $A_{59}$, and analyzed groundmass grains range from $\mathrm{An}_{76}$ to $\mathrm{An}_{26}$. Plagioclase $\mathrm{Fe}$ contents increase with decreasing An up to about $A_{60}$ to $\mathrm{An}_{65}$ and then decrease toward more albitic compositions (Figure 2). The inflection in the Fe versus An distribution probably marks the stage of crystallization at which $\mathrm{Fe}-\mathrm{Ti}$ oxides begin to crystallize, a conclusion supported by petrographic evidence and a similar inflection in $\mathrm{Ti}$ distributions in clinopyroxene. The change from nearly constant $\mathrm{Fe}$ to increasing $\mathrm{Fe}$ at $\mathrm{An}_{75}$ to $\mathrm{An}_{65}$ may mark the beginning of crystallization of clinopyroxene. This relationship is similar to that described by Ayuso et al. (1976) in other western Atlantic basalts.

Late-stage patches in some massive basalts consist of fine granophyric intergrowths of quartz and sodic plagioclase (Plate 3). Although individual grains in the intergrowths are too fine to probe, analyses of the intergrowths themselves indicate that the feldspar composition in the intergrowths ranges from $\mathrm{An}_{16}$ to $\mathrm{An}_{38}$ (Figure 3).

\section{Clinopyroxene}

Clinopyroxene compositions show considerable range in $\mathrm{Mg} /\left(\mathrm{Mg}+\mathrm{Fe}^{2+}\right)$ and in $\mathrm{Cr}_{2} \mathrm{O}_{3}, \mathrm{TiO}_{2}, \mathrm{Al}_{2} \mathrm{O}_{3}$, and $\mathrm{CaO}$ contents (Table 4). Phenocrysts have relatively restricted $\mathrm{Mg} / \mathrm{Fe}$ ratios, but span a range in $\mathrm{Ca} /\left(\mathrm{Mg}+\mathrm{Fe}^{2+}\right)$, partly due to compositional sector zoning (Figure 4). Groundmass grains in basalts and late-stage interstitial grains in dolerites extend to more iron-rich compositions; subcalcic $(\mathrm{CaO}$

TABLE 2

Representative Analyses of Olivine

\begin{tabular}{|c|c|c|c|c|c|c|c|c|c|}
\hline \multirow{3}{*}{$\begin{array}{c}\text { Hole } \\
\text { Lithologic Unit } \\
\text { Sample } \\
\text { (Interval in } \mathrm{cm} \text { ) }\end{array}$} & \multicolumn{5}{|c|}{ 417D } & \multicolumn{4}{|c|}{$418 \mathrm{~A}$} \\
\hline & $1 \mathrm{C}$ & 4 & \multicolumn{2}{|c|}{ 9D } & 1 & \multicolumn{2}{|c|}{$6 \mathrm{~B}$} & \multirow{2}{*}{$\begin{array}{l}11 \mathrm{~F} \\
71-4, \\
82-88\end{array}$} & \multirow{2}{*}{$\begin{array}{c}12 \mathrm{C} \\
80-1 \\
6-7\end{array}$} \\
\hline & $\begin{array}{c}35-5 \\
106-110\end{array}$ & $\begin{array}{l}41-7 \\
76-78\end{array}$ & $\begin{array}{l}62-2, \\
15-17\end{array}$ & $\begin{array}{c}64-4, \\
127-128\end{array}$ & $\begin{array}{c}15-1, \\
144-149\end{array}$ & $\begin{array}{l}46-4 \\
41-53\end{array}$ & $\begin{array}{l}48-3 \\
46-49\end{array}$ & & \\
\hline Anal. & 1 & 2 & 3 & 4 & 5 & 6 & 7 & 8 & 9 \\
\hline $\mathrm{SiO}_{2}$ & 39.7 & 39.4 & 39.4 & 39.9 & 40.1 & 39.8 & 39.8 & 39.5 & 40.1 \\
\hline $\mathrm{FeO}^{2}$ & 15.4 & 14.2 & 18.0 & 16.8 & 14.5 & 16.3 & 15.7 & 17.9 & 12.3 \\
\hline $\mathrm{MnO}$ & 0.30 & 0.24 & 0.27 & 0.27 & 0.24 & 0.31 & 0.22 & N.A. & N.A. \\
\hline $\mathrm{MgO}$ & 44.1 & 44.6 & 41.7 & 48.2 & 45.0 & 43.7 & 44.2 & 43.0 & 46.8 \\
\hline $\mathrm{CaO}$ & 0.33 & 0.35 & 0.34 & 0.32 & 0.37 & 0.31 & 0.35 & 0.33 & 0.32 \\
\hline Total & 99.8 & 98.8 & 99.7 & 100.1 & 100.2 & 100.4 & 100.3 & 100.7 & 99.5 \\
\hline \multicolumn{10}{|c|}{ Cations on the Basis of 4 Oxygens } \\
\hline $\mathrm{Si}$ & 1.001 & 0.999 & 1.004 & 1.009 & 1.003 & 1.002 & 1.000 & 0.997 & 0.999 \\
\hline $\mathrm{Fe}$ & 0.325 & 0.301 & 0.386 & 0.355 & 0.303 & 0.343 & 0.330 & 0.378 & 0.256 \\
\hline Mn & 0.006 & 0.005 & 0.006 & 0.006 & 0.005 & 0.007 & 0.005 & - & - \\
\hline $\mathrm{Mg}$ & 1.657 & 1.686 & 1.592 & 1.613 & 1.677 & 1.639 & 1.655 & 1.618 & 1.737 \\
\hline $\mathrm{Ca}$ & 0.009 & 0.010 & 0.009 & 0.009 & 0.010 & 0.008 & 0.009 & 0.009 & 0.009 \\
\hline Total & 2.998 & 3.001 & 2.997 & 2.992 & 2.997 & 2.998 & 3.000 & 3.003 & 3.001 \\
\hline Fo & 83.6 & 84.9 & 80.5 & 82.0 & 84.7 & 82.7 & 83.4 & 81.1 & 87.1 \\
\hline
\end{tabular}

Note: *Total Fe as FeO. N.A.: element not analyzed. 


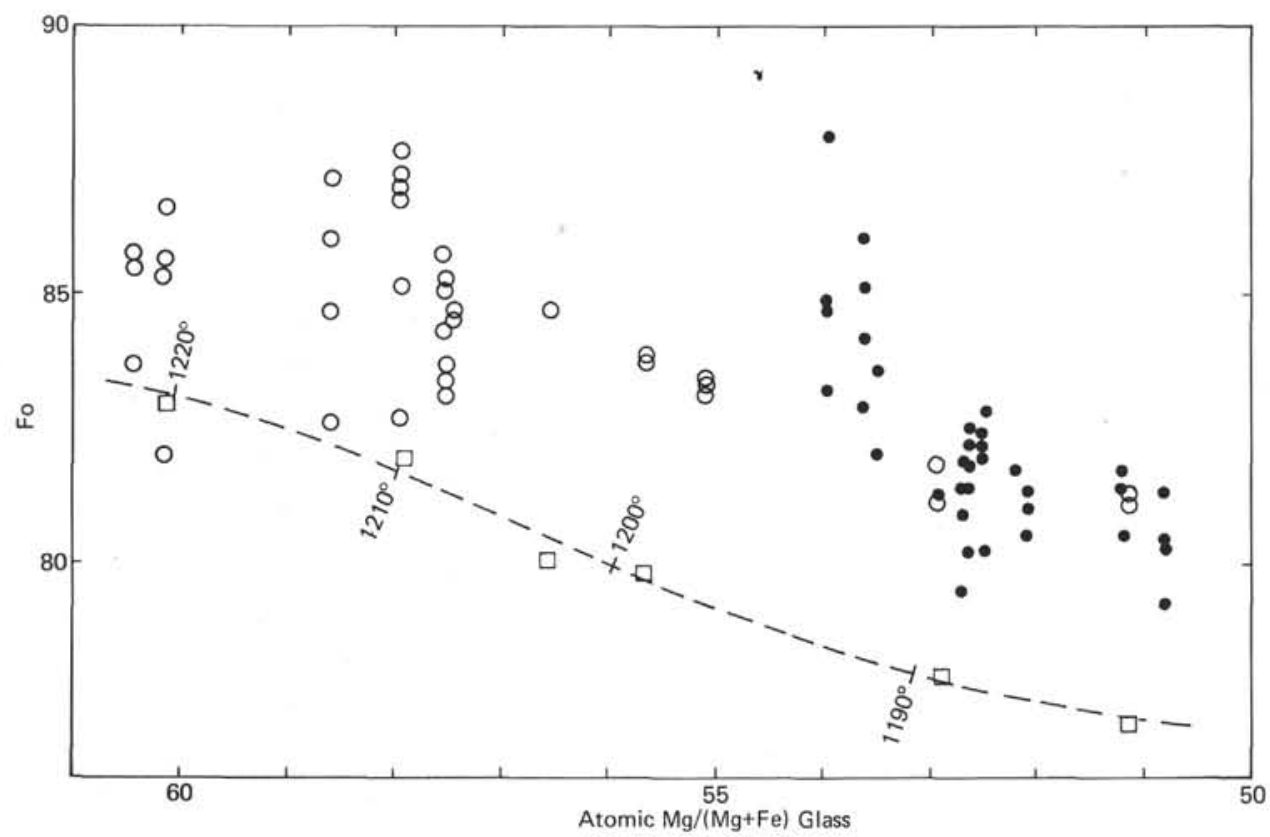

Figure 1. Mol. \% Fo in olivine versus atomic $\mathrm{Mg} /(\mathrm{Mg}+\mathrm{Fe})$ of the host glass for samples from Holes $417 \mathrm{D}$ (solid symbols) and $418 \mathrm{~A}$ (open symbols). The squares denote equilibrium olivine compositions and temperatures for six of the Hole $418 \mathrm{~A}$ glasses (from the data of Roedder and Emslie, 1970). Dashed line is drawn through these theoretical equilibrium points.

TABLE 3

Representative Analyses of Plagioclase

\begin{tabular}{|c|c|c|c|c|c|c|c|c|c|c|c|c|c|c|c|c|c|c|}
\hline Hole & \multicolumn{12}{|c|}{ 417D } & \multicolumn{6}{|c|}{$418 \mathrm{~A}$} \\
\hline Lithologic Unit & la & $1 \mathrm{~b}$ & \multicolumn{3}{|c|}{3} & \multicolumn{3}{|c|}{4} & 7 & \multicolumn{2}{|l|}{$9 a$} & 12 & $2 \mathrm{~d}$ & \multicolumn{2}{|l|}{$8 \mathrm{~b}$} & \multicolumn{2}{|c|}{$12 \mathrm{c}$} & \multirow{2}{*}{$\begin{array}{c}13 \\
79-4 \\
23-24 \\
\end{array}$} \\
\hline $\begin{array}{c}\text { Sample } \\
\text { (Interval in } \mathrm{cm} \text { ) }\end{array}$ & $\begin{array}{l}26-2 \\
89-92 \\
\end{array}$ & $\begin{array}{c}27-4 \\
131-136 \\
\end{array}$ & & $\begin{array}{l}33-5 \\
19-24\end{array}$ & & \multicolumn{3}{|c|}{$39-4,75 \cdot 82$} & $\begin{array}{l}45-2 \\
37-43 \\
\end{array}$ & \multicolumn{2}{|c|}{$52-4,24-27$} & $\begin{array}{l}67-3, \\
67-78 \\
\end{array}$ & $\begin{array}{l}20-5, \\
84-88 \\
\end{array}$ & \multicolumn{2}{|c|}{$58-3,50-54$} & \multicolumn{2}{|c|}{$80-1,6-7$} & \\
\hline Morphology & $\mathrm{Pc}$ & $\mathrm{Pc}$ & $\mathrm{Pc}$ & L & L & $\mathrm{Pc}$ & $\operatorname{Pr}$ & $\mathrm{Gm}$ & $\overline{\mathrm{Gl}}$ & $\mathrm{Pc}$ & $\mathrm{Pc}$ & $\mathrm{Gm}$ & $\overline{P c}$ & $\mathrm{R}$ & $\mathrm{Pr}$ & $\mathrm{Pc}$ & $\mathrm{Pc}$ & $\overline{P c}$ \\
\hline Anal. & 1 & 2 & 3 & 4 & 5 & $6 a$ & $6 \mathrm{~b}$ & 7 & 8 & 9 & 10 & 11 & 12 & $13 \mathrm{a}$ & $13 \mathrm{~b}$ & 14 & 15 & 16 \\
\hline $\mathrm{SiO}_{2}$ & 46.1 & 46.2 & 48.4 & 56.6 & 59.5 & 46.1 & 48.9 & 49.6 & 48.8 & 48.4 & 51.2 & 50.8 & 47.9 & 46.4 & 50.8 & 47.8 & 50.1 & 50.6 \\
\hline $\mathrm{Al}_{2} \mathrm{O}_{3}$ & 34.7 & 34.7 & 32.6 & 26.2 & 25.4 & 34.9 & 32.0 & 32.3 & 31.7 & 33.0 & 30.1 & 31.0 & 33.4 & 34.0 & 30.7 & 32.9 & 31.5 & 31.1 \\
\hline $\mathrm{FeO}^{*}$ & 0.39 & 0.46 & 0.51 & 0.79 & 0.68 & 0.42 & 0.51 & 0.67 & 0.55 & 0.56 & 0.68 & 0.74 & 0.42 & 0.35 & 0.70 & 0.36 & 0.63 & 0.65 \\
\hline $\mathrm{MgO}$ & 0.30 & 0.24 & 0.23 & 0.09 & 0.05 & 0.21 & 0.32 & 0.22 & 0.22 & 0.23 & 0.30 & 0.34 & 0.31 & 0.27 & 0.35 & 0.28 & 0.29 & 0.30 \\
\hline $\mathrm{CaO}$ & 18.2 & 17.7 & 16.3 & 9.35 & 7.18 & 17.2 & 15.2 & 15.4 & 15.2 & 15.7 & 13.7 & 14.2 & 16.4 & 17.2 & 13.7 & 16.6 & 14.8 & 14.6 \\
\hline $\mathrm{Na}_{2} \mathrm{O}$ & 0.93 & 1.20 & 2.13 & 6.08 & 7.30 & 1.25 & 2.46 & 2.58 & 2.68 & 2.34 & 3.53 & 3.29 & 1.93 & 1.50 & 3.45 & 1.92 & 2.97 & 3.14 \\
\hline $\mathrm{K}_{2} \mathrm{O}$ & 0.01 & 0.01 & 0.03 & 0.09 & 0.10 & 0.02 & 0.02 & 0.02 & 0.01 & 0.02 & 0.03 & 0.02 & 0.02 & 0.05 & 0.03 & 0.06 & 0.02 & 0.02 \\
\hline Total & 100.6 & 100.5 & 100.2 & 99.2 & 100.2 & 100.1 & 99.4 & 100.8 & 99.2 & 100.3 & 99.5 & 100.4 & 100.4 & 99.8 & 99.7 & 99.9 & 100.3 & 100.4 \\
\hline \multicolumn{19}{|c|}{ Cations on the Basis of 8 Oxygens } \\
\hline $\mathrm{Si}$ & 2.111 & 2.116 & 2.216 & 2.568 & 2.653 & 2.117 & 2.249 & 2.252 & 2.252 & 2.211 & 2.344 & 2.310 & 2.188 & 2.139 & 2.322 & 2.196 & 2.282 & 2.302 \\
\hline Al & 1.873 & 1.874 & 1.759 & 1.402 & 1.335 & 1.889 & 1.734 & 1.728 & 1.752 & 1.777 & 1.624 & 1.661 & 1.798 & 1.848 & 1.654 & 1.781 & 1.691 & 1.667 \\
\hline $\mathrm{Fe}$ & 0.015 & 0.018 & 0.020 & 0.030 & 0.025 & 0.016 & 0.020 & 0.025 & 0.021 & 0.021 & 0.026 & 0.028 & 0.016 & 0.013 & 0.027 & 0.014 & 0.024 & 0.025 \\
\hline $\mathrm{Mg}$ & 0.020 & 0.016 & 0.016 & 0.006 & 0.003 & 0.014 & 0.022 & 0.015 & 0.015 & 0.016 & 0.020 & 0.023 & 0.021 & 0.019 & 0.024 & 0.019 & 0.020 & 0.020 \\
\hline $\mathrm{Ca}$ & 0.893 & 0.869 & 0.800 & 0.454 & 0.343 & 0.846 & 0.749 & 0.749 & 0.752 & 0.768 & 0.672 & 0.692 & 0.803 & 0.850 & 0.671 & 0.817 & 0.722 & 0.712 \\
\hline $\mathrm{Na}$ & 0.083 & 0.107 & 0.189 & 0.535 & 0.631 & 0.111 & 0.219 & 0.227 & 0.240 & 0.207 & 0.313 & 0.290 & 0.171 & 0.134 & 0.306 & 0.171 & 0.262 & 0.277 \\
\hline K & 0.001 & 0.001 & 0.002 & 0.005 & 0.006 & 0.001 & 0.001 & 0.001 & 0.001 & 0.001 & 0.002 & 0.001 & 0.001 & 0.003 & 0.002 & 0.004 & 0.001 & 0.001 \\
\hline Total & 4.996 & 5.001 & 5.000 & 5.000 & 4.997 & 4.994 & 4.994 & 4.997 & 5.006 & 5.001 & 5.001 & 5.005 & 4.999 & 5.006 & 5.005 & 5.001 & 5.004 & 5.004 \\
\hline $\begin{array}{l}100 \mathrm{An} \\
\mathrm{An}+\mathrm{Ab}\end{array}$ & 91.4 & 88.9 & 80.7 & 45.7 & 35.0 & 88.3 & 77.3 & 76.7 & 75.7 & 78.7 & 68.1 & 70.4 & 82.4 & 86.1 & $68.5=$ & 82.4 & 73.3 & 71.9 \\
\hline
\end{tabular}

Note: - Total Fe as FeO. Pc: Phenocryst core. Pr: Phenocryst rim. R: Rounded megacryst. Gl: Glomeroporphyritic plagioclase. Gm: Groundmass grains in basalt. L: Late-stage interstitial grains in dolerites. Anal. a, b: Core and rim of same grain.

$<14$ wt. \%) grains in some dolerites co-exist with pigeonite (Plate 3, Figure 4). There is a strong correlation of $\mathrm{Ti} / \mathrm{Al}$ in clinopyroxene with decreasing $\mathrm{Mg} /\left(\mathrm{Mg}+\mathrm{Fe}^{+2}\right)$ (Figure 5).

Variation of $\mathrm{Ti}$ in clinopyroxene with decreasing $\mathrm{Mg} / \mathrm{Mg}$ $+\mathrm{Fe}^{2+}$ ) shows an inflection at $\mathrm{X}_{\mathrm{Mg}}^{\mathrm{cpx}}=0.72$ to 0.75 (Figure $6)$. This inflection is probably analogous to that in plagioclase (Figure 2), and petrographic examination indicates that pyroxene with $X_{\mathrm{Mg}}^{\mathrm{cpx}}=0.72$ to 0.75 co-exists with plagioclase of $A_{60}$ to $A_{65}$. The inflection in Ti versus $X_{M_{8}}$ probably reflects the consequent decrease in $\mathrm{Ti}$ in clinopyroxene as a result of the beginning of crystallization of $\mathrm{Fe}-\mathrm{Ti}$ oxides. In this interpretation $\mathrm{Mg} /\left(\mathrm{Mg}+\mathrm{Fe}^{2+}\right)$ of clinopyroxene represents an index of crystallinity and/or differentiation of the samples. 


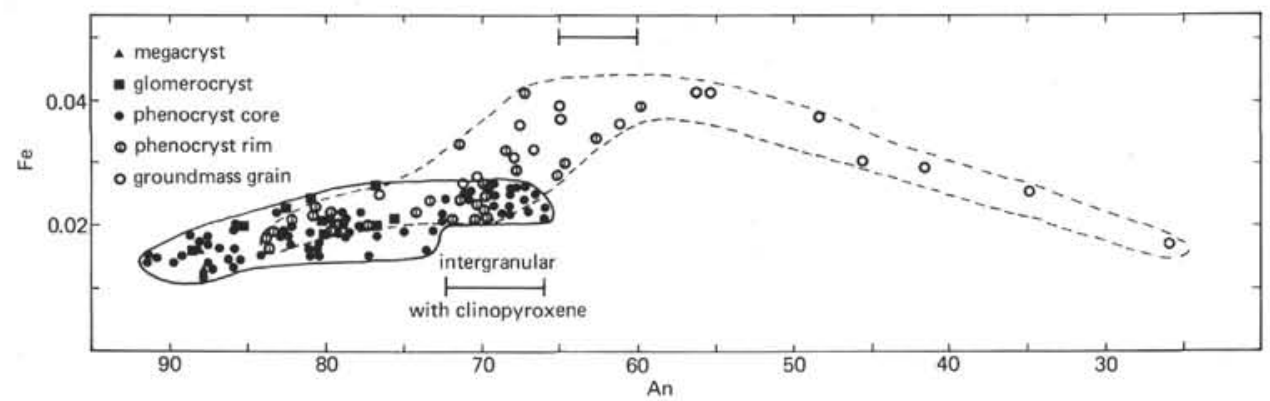

Figure 2. Mol. \% An versus Fe cations (on the basis of 8 oxygens per unit formula) in Hole $417 \mathrm{D}$ and $418 \mathrm{~A}$ plagioclase. Phenocrysts with compositions between $\mathrm{An}_{73}$ and An66 are intergrown with clinopyroxene (cf. Plate 2).

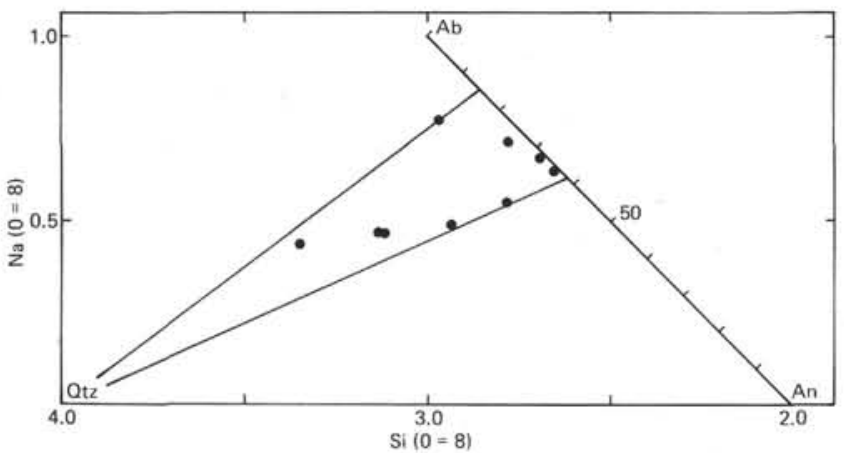

Figure 3. Na versus Si cations (on the basis of 8 oxygens) in granophyric intergrowths. Assuming the intergrowths are nearly pure plagioclase-quartz mixtures, the composition of the plagioclase component ranges from An 16 to An 38 .

\section{PHENOCRYST MORPHOLOGY AND EQUILIBRIUM CONSIDERATIONS}

Throughout the basement sections of both holes, there is ample evidence of pre-eruptive crystallization. Rounded, and possibly resorbed, phenocrysts of clinopyroxene and plagioclase have compositions indicating crystallization from liquids less differentiated than the glasses in which they now occur. Spinel inclusions in plagioclase also probably crystallized from fairly primitive liquids. Olivine phenocrysts, although generally euhedral, extend to highly magnesian compositions, even in samples with relatively fractionated glass compositions (Figure 1).

These phenomena either represent early crystals formed in hotter and possibly deeper levels of the magma conduit, or may reflect mixing of magmas. If the rounded grains do indeed represent resorbed cognate phenocrysts, then in the absence of large pressure variations, there must have been considerable thermal overturn in the chamber(s) prior to eruption. Alternatively, the rounded grains may have grown from fairly primitive liquids, and then been mixed with more evolved liquids, producing resorbed mafic grains in a relatively fractionated liquid.

Several observations are pertinent to this discussion. The compositional variation of glasses in each hole does not indicate simple progressive fractionation, but rather mixing of more and less fractionated liquids (Byerly and Sinton, this volume). Roundness of clinopyroxene cannot necessarily be taken as an indicator of resorption or disequilibrium, however. Later stage pyroxene phenocrysts intergrown with euhedral plagioclase laths (Plate 2) are also anhedral, and yet probably represent growth forms from the liquids in which they occur. This implies that clinopyroxene commonly grows round in these samples and that pyroxene morphology may be a poor criterion for evaluating equilibrium.

However, discrete rounded pyroxenes tend to have the most mafic compositions (Figure 7), and Fe-Mg partitioning considerations require them to have crystallized from fairly mafic liquids. The linearity of compositional correlations in Figures 4, 5, and 6 suggests that the range in liquid compositions from which pyroxene crystallized can probably be related by fractionation and a common crystallization history (see below). The glomeroporphyritic masses of pyroxene \pm plagioclase have similar compositional trends to other pyroxene phenocrysts and probably represent cognate phenocrysts, grown throughout the early crystallization stages of the rocks, and aggregated in the chambers prior to eruption.

Despite the conclusion that individual pyroxenes may not have been in equilibrium with the liquids (glasses) in which they occur, the compositional trends indicate that they apparently all grew in related or very similar fractionating liquids. Therefore, the pyroxene compositional trends can be used as indicators of the progressive evolution of the Hole 417D, 418A liquids in terms of their crystallization conditions and histories.

\section{PYROXENE CRYSTALLIZATION SUMMARY}

Assuming that $\mathrm{Mg} /(\mathrm{Mg}+\mathrm{Fe})$ represents an index of differentiation and/or stage of crystallization, it is evident that the earliest formed pyroxenes tend to be rounded discrete grains (Figure 7). Later stages of crystallization are characterized by glomeroporphyritic pyroxenes or intergrowths with plagioclase. Groundmass pyroxenes and interstitial grains in dolerites mark even later stages in the crystallization evolution of the samples. These textural criteria enable an evaluation of pyroxene crystallization trends in terms of the non-quadrilateral components $\mathrm{Na}, \mathrm{Ti}, \mathrm{Cr}, \mathrm{Al}^{\mathrm{IV}}$, and $\mathrm{Al}^{\mathrm{vr}}$. The following generalizations are apparent from Figures 8 and 9.

1) There is an early strong decrease in $\mathrm{Cr}$ in clinopyroxene, accompanied by nearly constant $\mathrm{Ti} / \mathrm{Al}{ }^{\mathrm{vI}}$. $\mathrm{Ti} / \mathrm{Ai}^{\mathrm{VI}}$ 
TABLE 4

Representative Analyses of Clinopyroxene

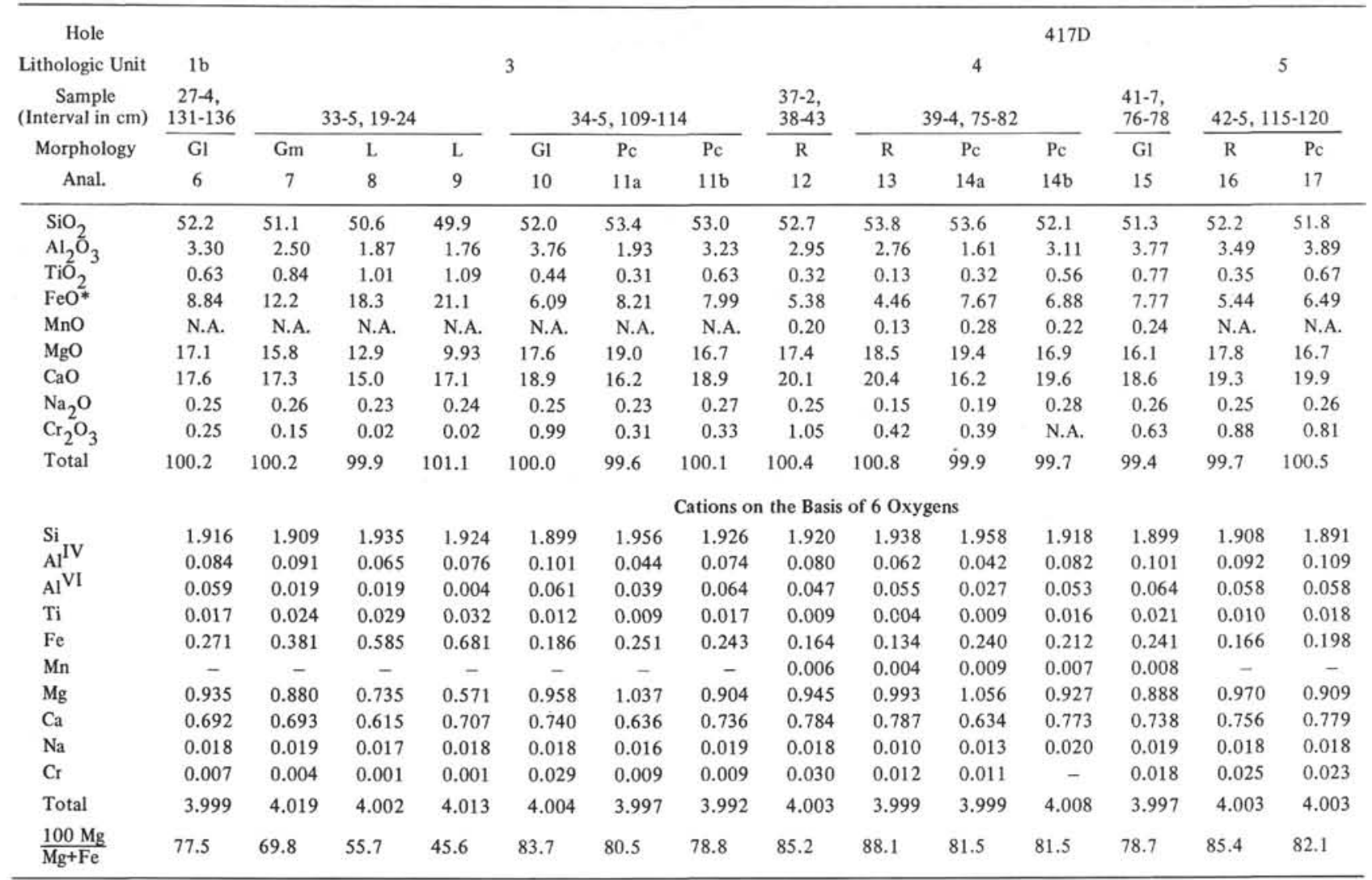

Note: *Total Fe as FeO. N.A.: Element not analyzed. Anal. a,b: opposing sectors in sector zoned phenocrysts. R: Rounded crystal in glass. Gl: Grain in glomeroporphyritic mass. Pc: Phenocryst, commonly intergrown with plagioclase; locally sector zone. Gm: Groundmass grains in basalts. O: Large grains in ophitic intergrowths with plagioclase in dolerites. L: Late-stage interstitial grains in massive units. **: Subcalcic clinopyroxene coexisting with pigeonite. Pg: Pigeonite.

shows a strong increase in the later stages of crystallization.

2) $\mathrm{Ti} / \mathrm{Al}^{\text {tot }}$ increases throughout the crystallization history.

3) $\mathrm{Ti}$ content increases up to an inflection point at $\mathrm{Mg} /(\mathrm{Mg}+\mathrm{Fe})=0.72$ to 0.75 .

4) $\mathrm{Na} / \mathrm{Ti}$ progressively decreases with crystallization; there is an excess of $\mathrm{Na}$ in early pyroxenes and an excess of $\mathrm{Ti}$ in later stages.

To interpret these trends, it is convenient to consider the elements $\mathrm{Al}, \mathrm{Cr}$, and $\mathrm{Na}$, as well as $\mathrm{Ca}, \mathrm{Fe}$, and $\mathrm{Mg}$ in terms of the pyroxene components (Kushiro, 1962): Di (diopside $-\mathrm{CaMgSi}_{2} \mathrm{O}_{6}$ ), $\mathrm{Hd}$ (hedenbergite $-\mathrm{CaFeSi}_{2} \mathrm{O}_{6}$ ), En (enstatite - $\mathrm{Mg}_{2} \mathrm{Si}_{2} \mathrm{O}_{6}$ ), Fs (ferrosilite $-\mathrm{Fe}_{2} \mathrm{Si}_{2} \mathrm{O}_{6}$ ), CaTs (Ca-Tschermak's component - $\mathrm{CaAl}^{\mathrm{iv}} \mathrm{Al}^{\mathrm{vi}} \mathrm{SiO}_{6}$ ), CrCaTs

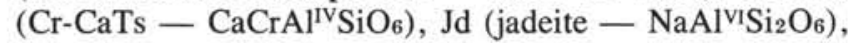
and $\mathrm{Ac}$ (acmite $-\mathrm{NaFe}^{3+} \mathrm{Si}_{2} \mathrm{O}_{6}$ ). $\mathrm{Ti}$ in clinopyroxene is generally considered to occur as $\mathrm{CaTiAl}_{2}{ }^{\mathrm{IV}} \mathrm{O}_{6}$ (Kushiro, 1962; Nakamura and Coombs, 1973).

\section{Early Stages of Pyroxene Crystallization}

The initial increase in $\mathrm{Ti}$ in pyroxene with decreasing $\mathrm{Mg} /(\mathrm{Mg}+\mathrm{Fe})$ probably reflects a general increase in the $\mathrm{Ti}$ content of the liquid with differentiation. This typically tholeiitic feature (e.g., Miyashiro, 1974) results from early differentiation being mainly controlled by the Ti-free min- erals olivine and plagioclase. Increasing Ti with nearly constant $\mathrm{Ti} / \mathrm{Al}^{\mathrm{Vl}}$ and increasing $\mathrm{Ti} / \mathrm{Al}^{\text {total }}$ means there must be an early decrease in $\mathrm{Al}^{\mathrm{v}}$ and a concomitant increase in $\mathrm{Al}^{\mathrm{Vl} /}$ $\mathrm{Al}^{\mathrm{Iv}}$. In low-Ti pyroxenes such as these, Aliv can be considered to be mainly present as CaTs and CrCaTs (Nakamura and Coombs, 1973). Decreasing Ts component in clinopyroxene co-existing with plagioclase either reflects increasing activity of silica in the host magma (Kushiro, 1960; LeBas, 1962) or decreasing pressure (Kushiro, 1965), or both. Similarly, the excess $\mathrm{Na}$ in early-stage pyroxenes probably reflects the presence of significant Jd component, which is also favored at high pressures.

\section{Post-Inflection Crystallization}

After Ti-magnetite starts to crystallize, Ti contents (Ca$\mathrm{TiAl}_{2} \mathrm{O}_{6}$ ) remain nearly constant. Increasing $\mathrm{Ti} / \mathrm{Al}^{\mathrm{VI}}$ and $\mathrm{Ti} / \mathrm{Al}^{\text {total }}$ with constant $\mathrm{Ti}$, means that both $\mathrm{Alv}$ and total $\mathrm{Al}$ are decreasing, which probably reflects decreased solubilities of CaTs and/or Jd components with crystallization. Since Na contents are approximately constant throughout the crystallization sequence, decreased solubility of Jd component is apparently balanced by substitutions of $\mathrm{Fe}^{3+}$ for $\mathrm{Al}$ (i.e., increasing acmite at the expense of jadeite). Subcalcic augites co-existing with pigeonite probably represent metastable rapid growth phenomena since there is no 
TABLE 4 - Continued

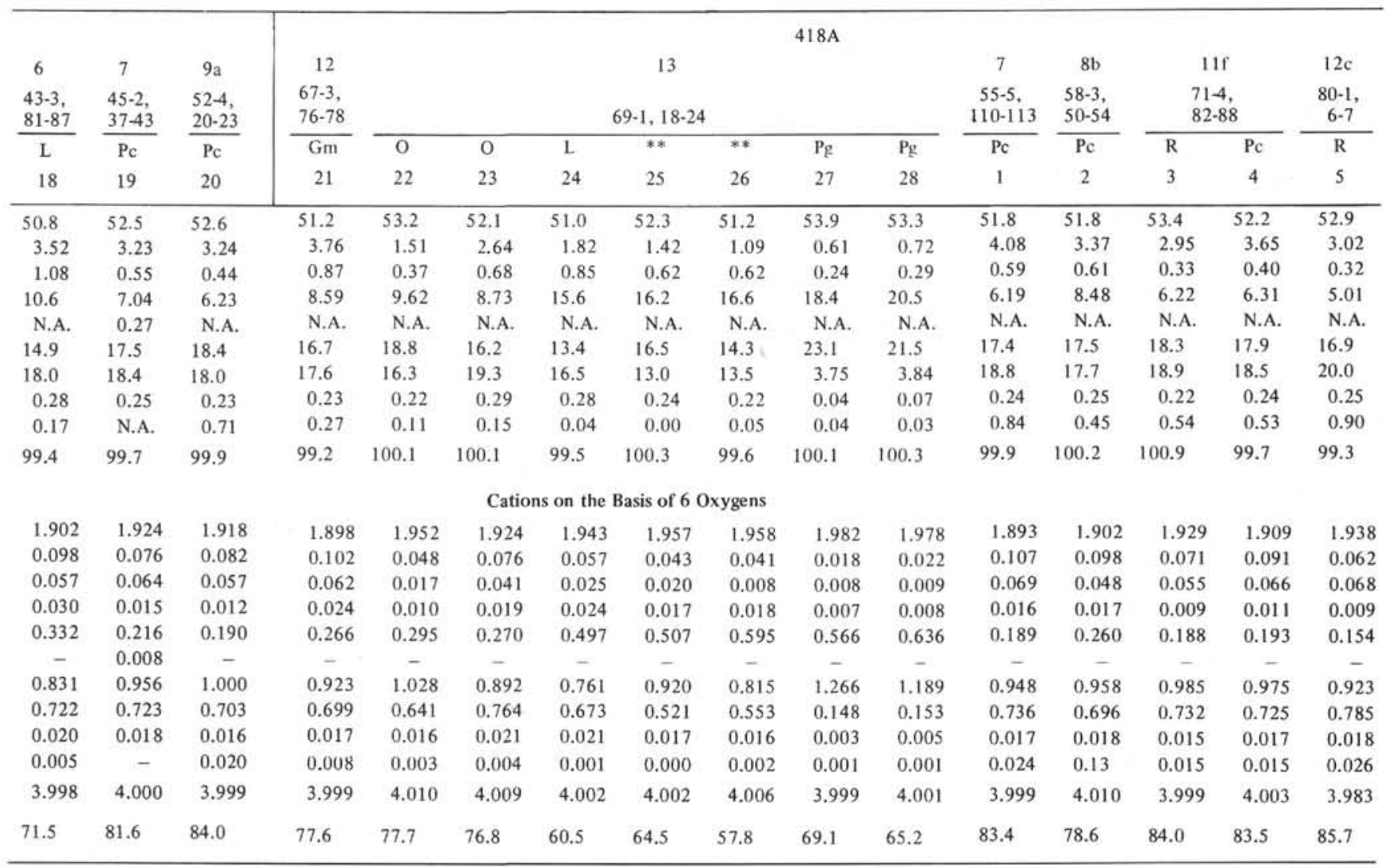

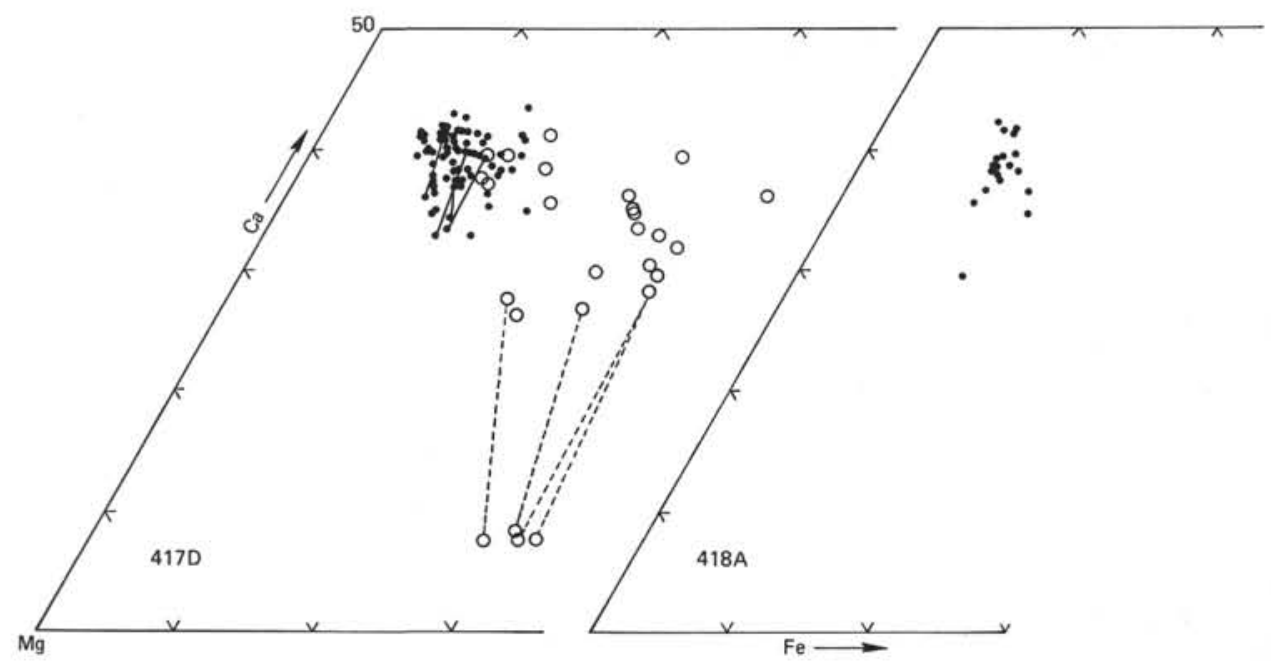

Figure 4. Hole 417D and $418 \mathrm{~A}$ clinopyroxene compositions plotted in terms of atomic $\mathrm{Ca}-\mathrm{Fe}-\mathrm{Mg}$ for phenocryst (solid symbols) and groundmass (open symbols) grains. Solid tie lines connect opposing sectors in sector zoned grains. Dashed lines connect coexisting subcalcic augite and pigeonite.

known equilibrium miscibility in this compositional region at magmatic temperatures (e.g., Brown, 1957; Atkins, 1969; Nakamura and Coombs, 1973).

In summary, the pyroxene compositional trends indicate crystallization from progressively rising and fractionating magma batches. Silica activity may have been progressively increasing during crystallization. Although it is not possible to quantify the range of pressure over which the pyroxenes crystallized, the entire range must be at pressures less than that in which pyroxene replaces olivine on the liquidus 


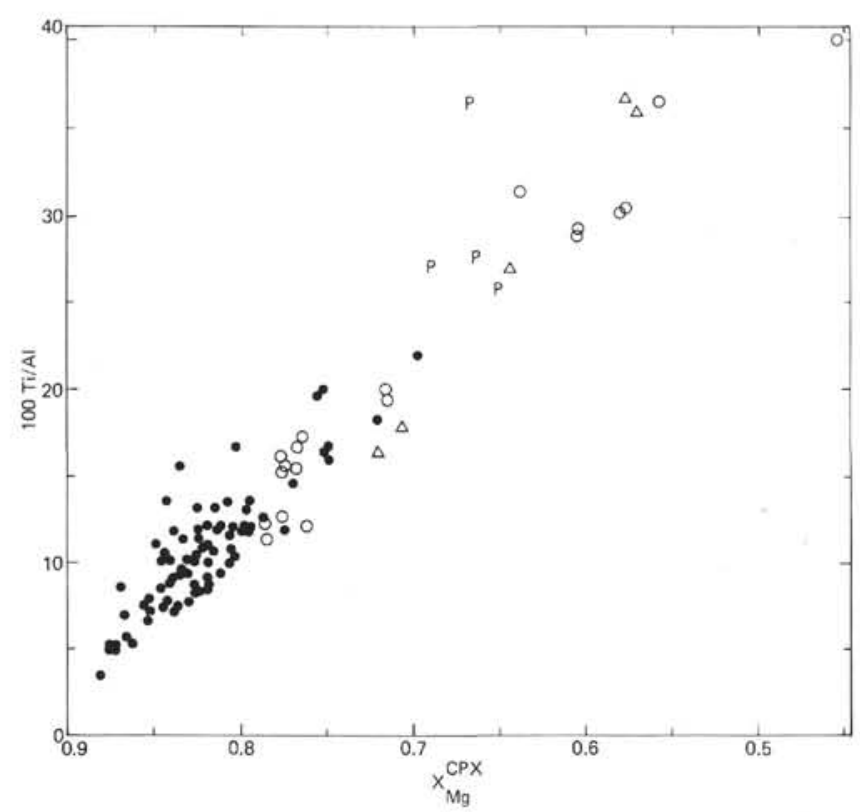

Figure 5. Atomic ratio $100 \mathrm{Ti} / \mathrm{Al}$ versus $X_{M g}^{c p x}[=\mathrm{Mg} /(\mathrm{Mg}$ $+\mathrm{Fe})_{\text {cpx }}$ l in Hole $417 \mathrm{D}$ and $418 \mathrm{~A}$ clinopyroxene phenocrysts (solid circles), groundmass grains (open circles), subcalcic augites (triangles), and pigeonite ( $P$ ).

(about 7kbar, Kushiro, 1973), since pyroxene apparently started to crystallize after olivine and plagioclase in all samples.

\section{LATE-STAGE CRYSTALLIZATION}

In some massive units, isolated patches contain $\mathrm{Fe}-\mathrm{Ti}$ oxides and fine intergrowths of quartz, Na-plagioclase, and tiny needles of apatite (?). Associated pyroxenes tend to higher $\mathrm{Fe}$ and lower $\mathrm{Ca}$ contents than the ophitic pyroxenes that make up the rest of the rock. Pigeonite occurs as rare intergrowths with subcalcic pyroxene or as cores to some grains (Plate 3 ). The patches account for about 5 per cent of some samples and probably represent highly differentiated liquids from at least 95 per cent crystallization. They are therefore indicative of the late products of fractionation of the Hole 417D, 418 magmas.

The assemblage quartz-oligoclase-pyroxene-oxide \pm apatite is representative of relatively high $\mathrm{SiO}_{2}$ compositions, yet potassium contents are still very low. These compositions are analogous to trondhjemitic rocks of ophiolite complexes (e.g., Coleman and Peterman, 1975) and are similar to the rhyodacites recovered from the Galapagos spreading center (Byerly et al., 1976; Byerly, in prep.). The presence of such patches provides the first direct evidence that ocean floor basaltic liquids may evolve to high silica, high $\mathrm{Na} / \mathrm{K}$ differentiates.

\section{CRYSTALLIZATION HISTORY AND SUMMARY}

The earliest stage of crystallization for which evidence is retained in the rocks involves spinel, plagioclase, and olivine. Spinel inclusions in plagioclase indicate that the oxide may have been the first phase to form in these liquids. Plagioclase and olivine occur together only in the magnesian upper units (1 to 6) of $418 \mathrm{~A}$ where it appears that plagioclase was the earlier phase. Large plagioclase grains up to $A_{91}$ represent the most primitive feldspars in these rocks.

The first formed pyroxenes are discrete rounded grains with $\mathrm{Mg} /\left(\mathrm{Mg}+\mathrm{Fe}^{2+}\right)$ up to values of 0.88 . Initiation of pyroxene crystallization is marked in feldspar compositions by a change from nearly constant $\mathrm{Fe}$ contents, to gradually increasing $\mathrm{Fe}$. This effect was also noted in plagioclase in Leg 11 basalts (Ayuso et al., 1976). Although spinel apparently continued to form in the groundmasses of the leastfractionated units (e.g., Hole 418A lithologic Unit 6), there is no evidence that spinel and pyroxene ever co-precipitated, possibly controlled by a peritectic reaction relationship (Irvine, 1967), which is indicative of low to moderate crystallization pressures (somewhere less than $10 \mathrm{kbar}$, Osborn and Arculus, 1975).

The beginning of crystallization of Fe-Ti oxides is marked by inflections in the feldspar and pyroxene compositional trends (Figure 10). Textural evidence supports the

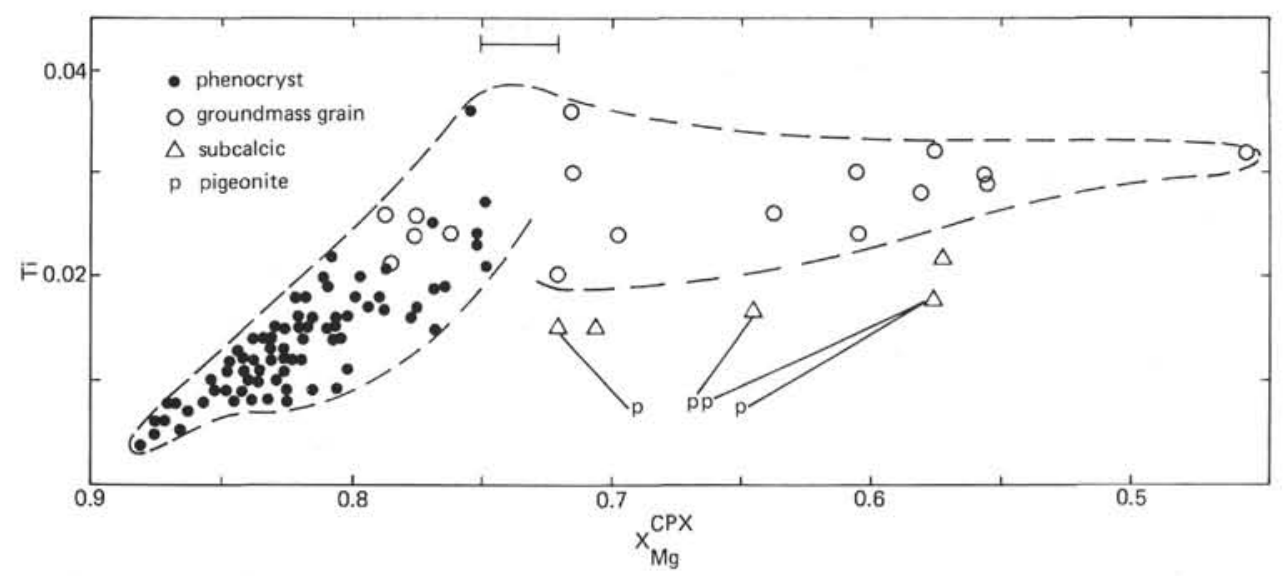

Figure 6. $X_{M g}^{c p x}$ versus Ti cations (per 6 oxygens) in Hole 417D and $418 \mathrm{~A}$ clinopyroxenes. Symbols as in Figure 5. Compositions between $X_{M g}^{c p x}=0.72$ and 0.75 co-exist with plagioclase of composition An $60-65$ and mark the inflection point in the pyroxene data. 


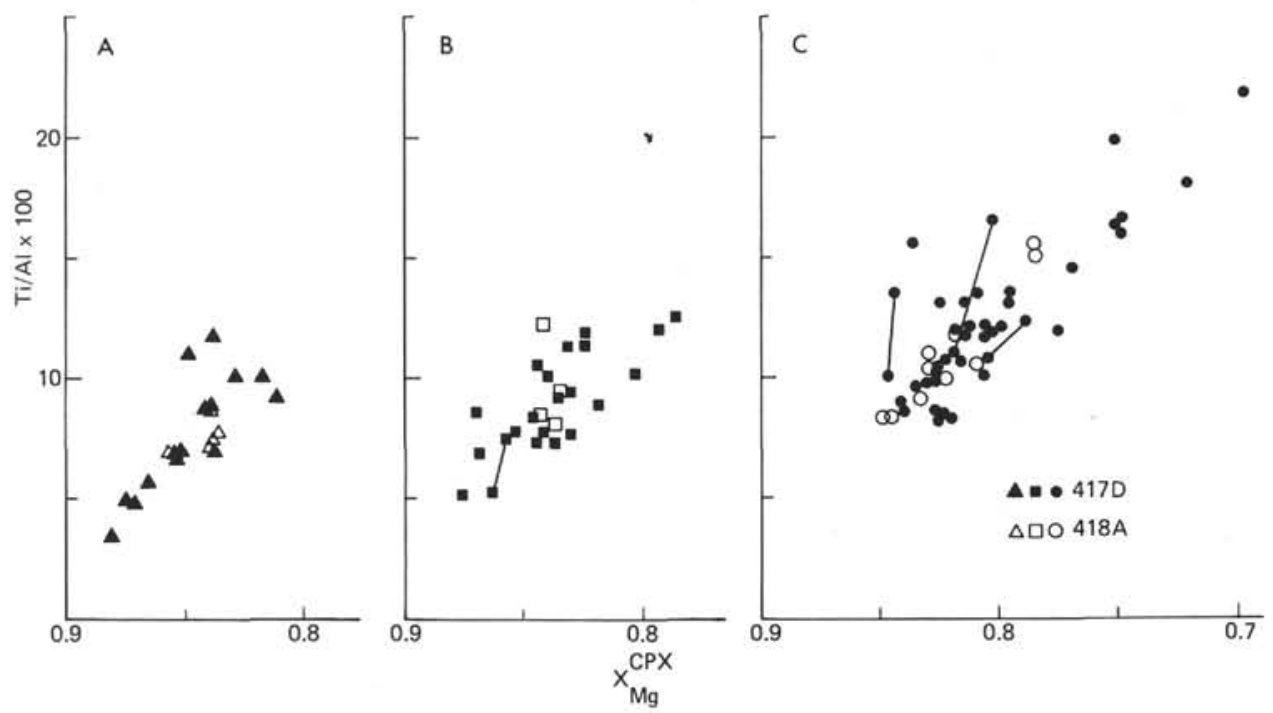

Figure 7. Atomic ratio $100 \mathrm{Ti} / \mathrm{Al}$ versus $X_{M g}^{c p x}$ in clinopyroxene phenocrysts from Hole $417 \mathrm{D}$ (solid symbols) and $418 \mathrm{~A}$ (open symbols) by morphology: (A) discrete rounded clinopyroxene grains, commonly occurring in glass, (B) pyroxenes in glomeroporphyritic aggregates with other pyroxenes and plagioclase, (C) pyroxenes intergrown with plagioclase. Tie lines connect opposing sectors of sector zoned grains.

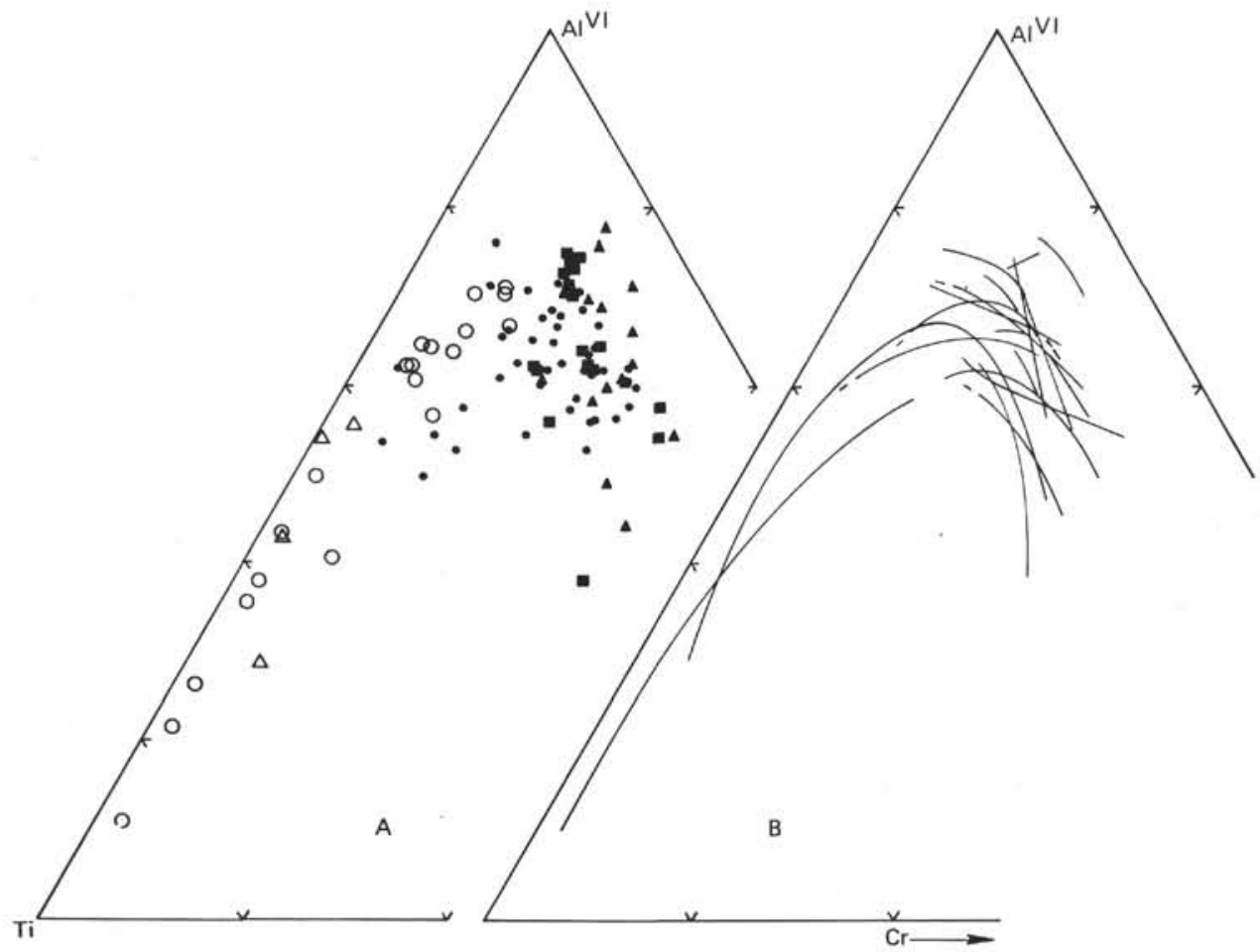

Figure 8. Hole $418 D$ and $418 \mathrm{~A}$ pyroxene compositions plotted in terms of the Ml components $A l^{V I}, T i$, and $C r$. (A) By morphology, solid symbols as in Figure 7, open symbols as in Figure 5. (B) Trend lines for individual samples. There is no apparent relationship between position on this diagram and chemical type of Byerly and Sinton (this volume).

conclusion based on plagioclase and clinopyroxene inflections that magnetite starts to form only after crystallization has proceeded to where plagioclase has the composition $\mathrm{An}_{60}$ to $\mathrm{An}_{65}$ and $\mathrm{Mg} /\left(\mathrm{Mg}+\mathrm{Fe}^{2+}\right)$ of clinopyroxene $=0.72$ to 0.75 . Subcalcic augite and pigeonite form rare late-stage grains in some ophitic dolerites. Quartz and possibly apatite are the last phases to form; they occur with oligoclase in very late stage segregation patches in some massive units. 

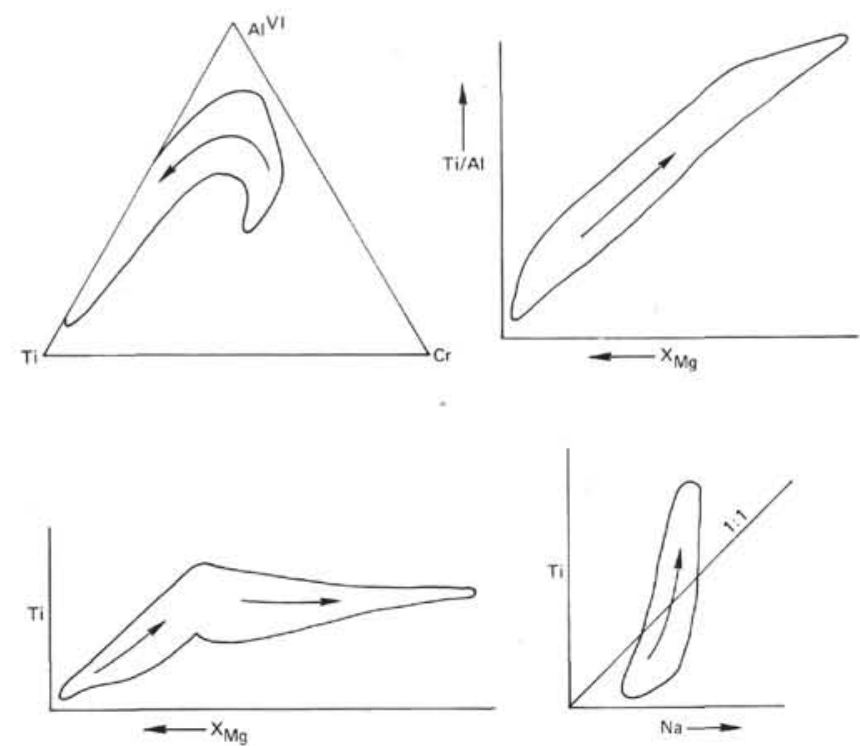

Figure 9. Summary of Hole 417D and 418A clinopyroxene crystallization trends. See text for discussion.

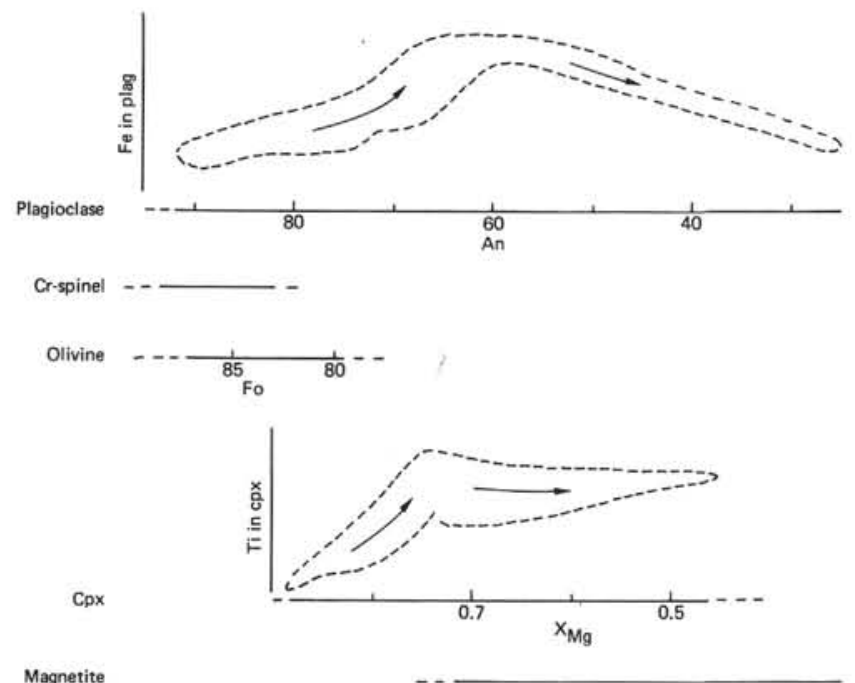

Quartz

Figure 10. Crystallization summary of Hole $417 D$ and $418 \mathrm{~A}$ samples. The beginning of crystallization of magnetite is aligned with the inflections in the plagioclase and clinopyroxene trends.

\section{ACKNOWLEDGMENTS}

We both thank the Smithsonian Institution for fellowship support, use of facilities, and invaluable help from numerous staff members, especially Tim O'Hearn and Richard Johnson. Sinton thanks the Deep Sea Drilling Project for support to participate on Leg 51 and for funds to offset manuscript preparation costs. Byerly thanks the Deep Sea Drilling Project for support to participate on
Leg 52. Hubert Staudigel sampled for us on Leg 53. The captains and crew of Glomar Challenger and the DSDP technical staff provided a pleasant and efficient working environment at sea. The manuscript was substantially improved through critical reviews by Bob Ayuso, Mike Garcia, and Rita Pujalet.

\section{REFERENCES}

Atkins, F.B., 1969. Pyroxenes of the Bushveld Intrusion, South Africa, Journal of Petrology, v. 10, p. 229-249.

Ayuso, R.A., Bence, A.E., and Taylor, S.R., 1976. Upper Jurassic tholeiitic basalts from DSDP Leg 11, Journal of Geophysical Research, v. 81, p. 4305-4325.

Brown, G.M., 1957. Pyroxenes from the early and middle stages of fractionation of the Skaergaard Intrusion, East Greenland, Mineralogical Magazine, v. 31, p. 511-543.

Bryan, W.B., 1972a. Mineralogical studies of submarine basalts, Carnegie Institution of Washington Yearbook, v. 71, p. 396403.

, 1972b. Morphology of quench crystals in submarine basalts, Journal of Geophysical Research, v. 77, p. 58125819.

Byerly, G.R., Melson, W.G., and Vogt, P.R., 1976. Rhyodacites, andesites, ferro-basalts and ocean tholeiites from the Galapagos spreading center, Earth and Planetary Science Letters, v. 30, p. 215-221.

Coleman, R.G. and Peterman, Z.E., 1975. Oceanic plagiogranite, Journal of Geophysical Research, v. 80, p. 1099-1108.

Irvine, T.N., 1967. Chromian spinel as a petrogenetic indicator. Part II: Petrologic applications, Canadian Journal of Earth Science, v. 4, p. 71-103.

Kushiro, I., 1960. Si-Al relations of clinopyroxenes from igneous rocks, American Journal of Science, v. 258, p. 548-554.

, 1962. Clinopyroxene solid solutions, Part I: The Ca$\mathrm{Al}_{2} \mathrm{SiO}_{6}$ component, Japanese Journal of Geology and Geography, v. 33, p. 213-220.

,1965. Clinopyroxene solid solutions at high pressures, Carnegie Institution of Washington Yearbook, v. 64, p. 112117.

1973. Origin of some magmas in oceanic and circum-oceanic regions, Tectonophysics, v. 17, p. 211-222.

LeBas, M.J., 1962. The role of aluminum in igneous clinopyroxenes with relation to their parentage, American Journal of Science, v. 260 , p. $267-288$.

Lofgren, G., 1974. An experimental study of plagioclase crystal morphology: Isothermal crystallization, American Journal of Science, v. 274 , p. 243-273.

Miyashiro, A., 1974. Volcanic rock series in island arcs and active continental margins, American Journal of Science, v. 274, p. 321-355.

Nakamura, Y. and Coombs, D.S., 1973. Clinopyroxenes in the Tawhiroko tholeiitic dolerite at Moeraki, north-eastern Otago, New Zealand, Contributions to Mineralogy and Petrology, v. 42 , p. $213-228$.

Osborn, E.F. and Arculus, R.J., 1975. Phase relations in the system $\mathrm{Mg}_{2} \mathrm{SiO}_{4}$ - iron oxide $-\mathrm{CaAl}_{2} \mathrm{Si}_{2} \mathrm{O}_{8}-\mathrm{SiO}_{2}$ at $10 \mathrm{Kbar}$ and their bearing on the origin of andesite, Carnegie Institution of Washington Yearbook, v. 74, p. 504-507.

Roedder, P.L. and Emslie, R.F., 1970. Olivine-liquid equilibria, Contributions to Mineralogy and Petrology, v. 29, p. 275-289.

Sinton, J.M., 1979. Petrology of (alpine-type) peridotites from Site 395, DSDP Leg 45. In Melson, W.G., Rabinowitz, P.D., et al., Initial Reports of the Deep Sea Drilling Project, v. 45 Washington (U.S. Government Printing Office), p. 595-602. 

PLATE 1

Plagioclase Morphologies and Quench Textures

Figure 1 Rounded plagioclase core (An 86) with rapidly crystallized overgrowth (An 68.5), Sample 418A-58-3, 50-54 cm. X-polars.

Figure 2 Sector zoned plagioclase phenocryst, Sample 417D$66-4,74-76 \mathrm{~cm}$. X-polars.

Figure 3 Rapidly crystallized texture with skeletal plagioclase, Sample 417D-62-1, 94-96 cm. Plain light.

Figure 4 Rapidly crystallized clinopyroxene and plagioclase, Sample 417D-67-3, 76-78 cm. Plain light.

Figure 5 Skeletal plagioclase, Sample 417D-31-2, 127-130 $\mathrm{cm}$. Plain light.

Figure 6 Skeletal spinels in Sample 418A-48-3, 46-47 cm. Included material in spinels is devitrified glass. Bright patches in spinels are sulfides. The large grain is nearly completely altered olivine. Reflected light. 


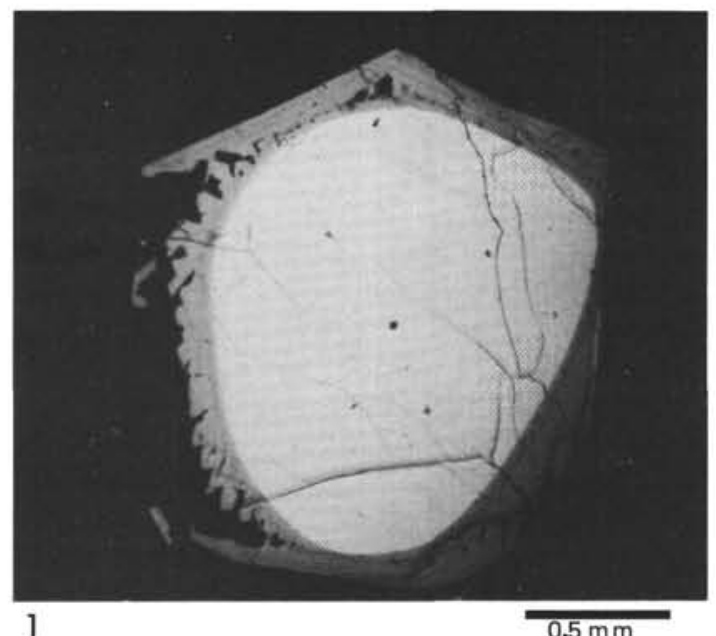

PLATE 1

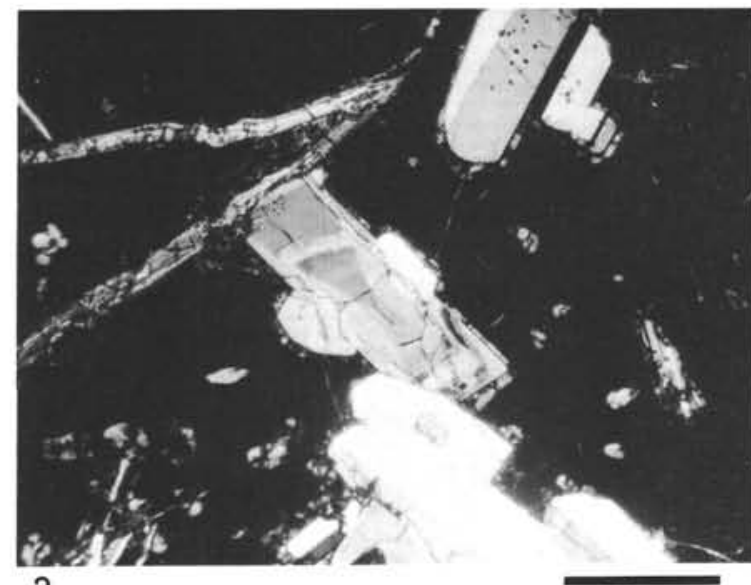

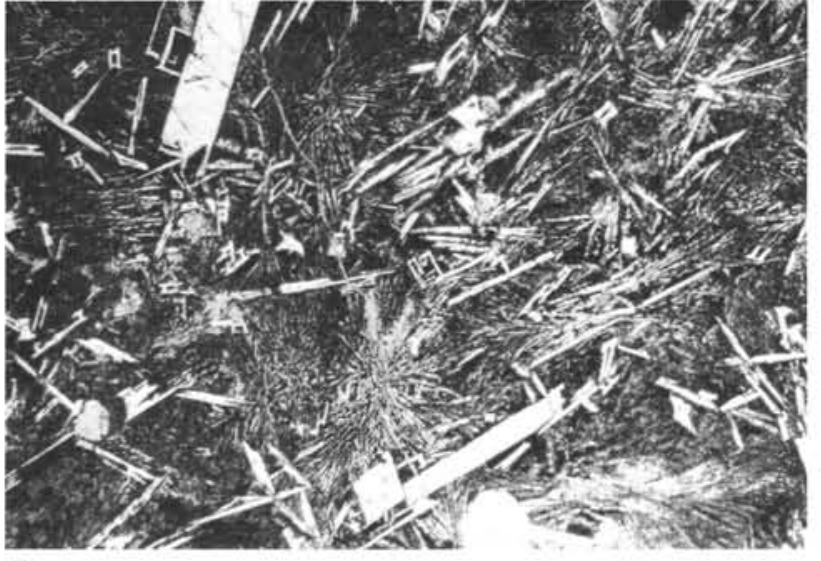

3

$0.5 \mathrm{~mm}$

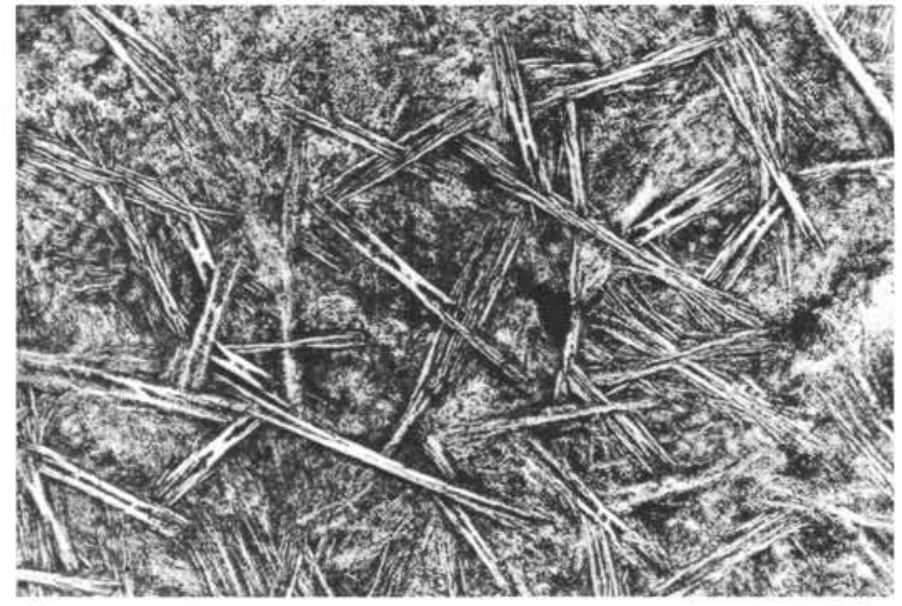

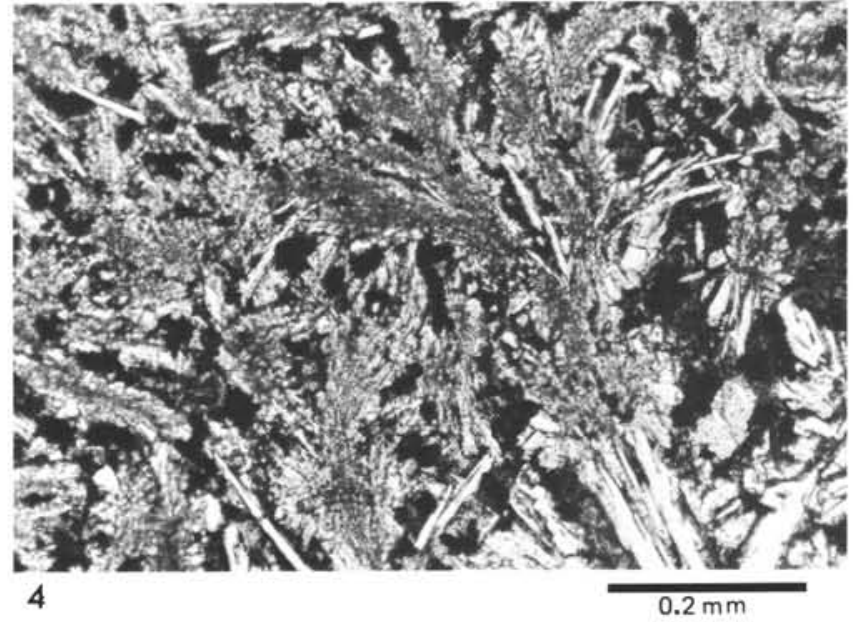

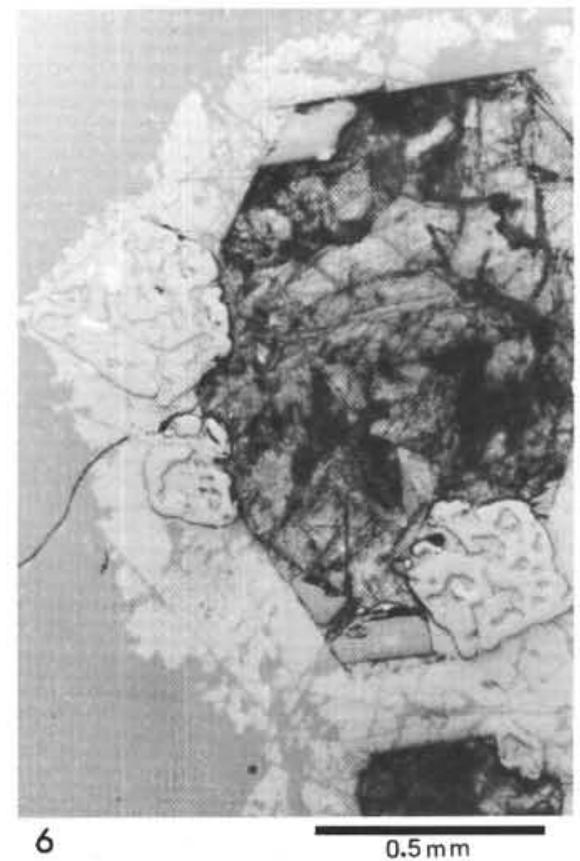


PLATE 2

Clinopyroxene Morphologies

Figure 1 Rounded clinopyroxene, Sample 417D-22-7, 28-32 $\mathrm{cm}$. Plain light.

Figure 2 Irregular glomeroporphyritic clinopyroxene patch in glass, Sample 417D-62-2, 15-17 cm. X-polars.

Figure 3 Rounded clinopyroxene phenocrysts, partially enclosing euhedral plagioclase laths, Sample 417D-42-5, $115-120 \mathrm{~cm}$. Plain light. Note spherulitic texture in upper right.

Figure 4 Anhedral clinopyroxene phenocryst with euhedral plagioclase inclusion. Matrix is devitrified glass. Sample 417D-44-4, 50-57 cm. Plain light.

Figure 5 Anhedral clinopyroxene with irregular outline, partially enclosing euhedral plagioclase, Sample 418A79-4, 23-24 cm. X-polars. 

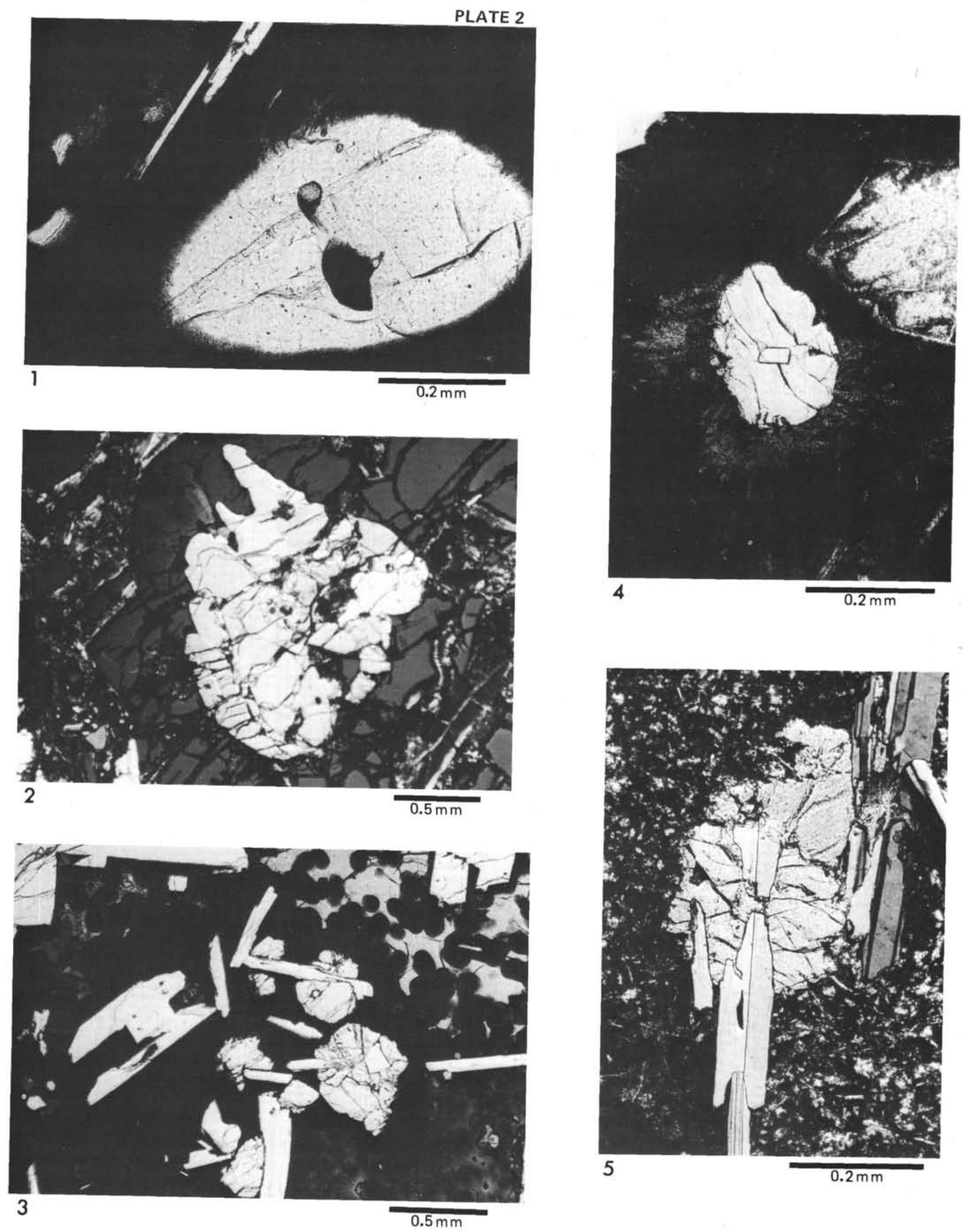


\section{PLATE 3}
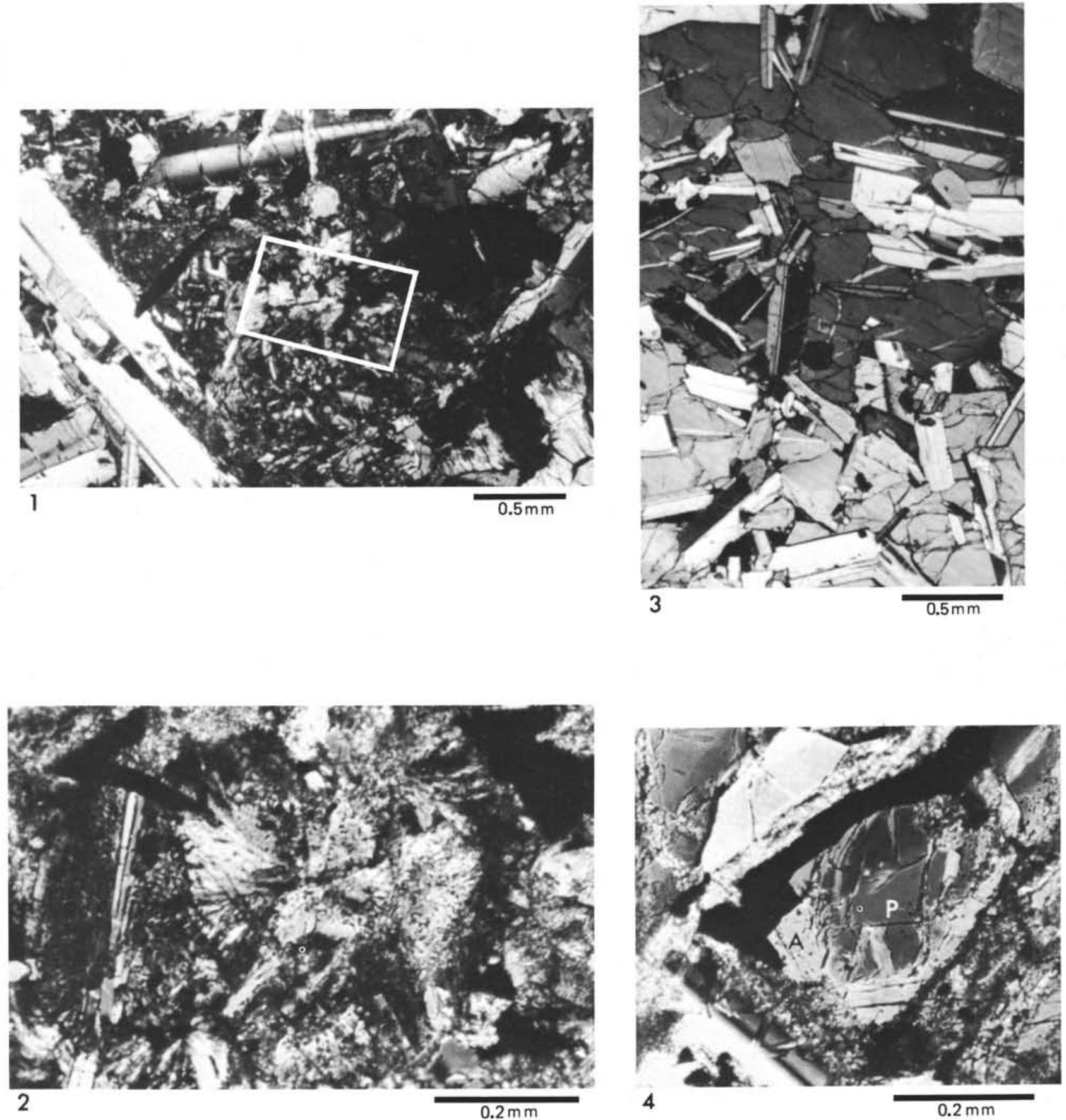

Textures in Massive Dolerite Sample 417D-69-1, 18-24 cm.

Figure $1 \quad$ Late-stage granophyric patch, X-polars. Enclosed area outlines the field of Figure 2.

Figure 2 Enlarged view of late-stage patch with granophyric intergrowths of quartz and Na-plagioclase, X-polars.

Figure 3 Ophitic texture with coarse clinopyroxene enclosing plagioclase, X-polars.

Figure 4 Subcalcic augite $(\mathrm{A})$ rim on pigeonite $(\mathrm{P}), \mathrm{X}$-polars. 